\title{
IMPLEMENTASI MODEL PROBLEM BASED INSTRUCTION TERHADAP PENGUASAAN MATERI HUKUM NEWTON DAN KECAKAPAN BERPIKIR KRITIS SISWA
}

\author{
Umayya Ulfa ${ }^{1}$, Anggu Winata ${ }^{2}$ \\ Universitas Sunan Bonang ${ }^{1}$, Universitas PGRI Ronggolawe Tuban ${ }^{2}$ \\ umayyaulfah5@gmail.com ${ }^{1}$
}

\begin{abstract}
This study aims to determine the difference in the achievement of students' average scores between the implementation of the problem based instruction (PBI) model and conventional learning on student activities, mastery of Newton's Law material, and students' critical thinking skills. This research method is a true experiment using a randomized control-group pre-test-post-test design, where the experimental class and the control class are given pre-test and post-test. The results of this study indicate, a) in the psychomotor aspect, the percentage of the good category for the experimental class is on average higher than the control class, while in the affective aspect there is no significant difference; $b$ ) there is a significant difference in the mastery of Newton's Law material between students taught through the implementation of the PBI model with an average change in value of 56.59 compared to conventional learning of 46.14; c) there is a significant difference in critical thinking skills between students taught through the implementation of the PBI model with an average change in score of 55.85 compared to conventional learning of 45.62. The conclusion, that the implementation of PBI the average score of psychomotor activity, mastery of Newton's Law material, and students' critical thinking skills are significantly different compared to conventional learning.
\end{abstract}

Keywords: Critical Thinking Skills, Newton's Law Material, Problem Based Instruction Model, Conventional Learning

\begin{abstract}
Abstrak: Penelitian ini bertujuan mengetahui perbedaan pencapaian skor rata-rata siswa antara implementasi model problem based instruction (PBI) dan pembelajaran konvensional terhadap aktivitas siswa, penguasaan materi Hukum Newton, dan kecakapan berpikir kritis siswa. Metode penelitian ini adalah penelitian yang sebenarnya (true experiment) dengan menggunakan rancangan penelitian randomized control-group pre test-post test design, dimana kelas eksperimen dan kelas kontrol diberi pre tes dan post tes. Hasil penelitian ini menunjukkan, a) pada aspek psikomotor persentase kategori baik untuk kelas eksperimen rata-ratanya lebih tinggi daripada kelas kontrol, sedangkan pada aspek afektif tidak menunjukkan adanya perbedaan yang berarti; $b$ ) terdapat perbedaan signifikan penguasaan materi Hukum Newton antara siswa yang diajarkan melalui implementasi model PBI dengan perolehan rata-rata perubahan nilai 56,59 dibandingkan dengan pembelajaran konvensional sebesar 46,14; c) terdapat perbedaan signifikan kecakapan berpikir kritis antara siswa yang diajarkan melalui implementasi model PBI dengan pencapaian rata-rata perubahan nilai 55,85 dibandingkan dengan pembelajaran konvensional sebesar 45,62. Simpulan, bahwa implementasi PBI perolehan skor rata-rata aktifitas psikomotor, penguasaan materi Hukum Newton, dan kecakapan berpikir kritis siswa berbeda secara signifikan dibandingkan dengan pembelajaran konvensional
\end{abstract}

Kata Kunci: Kecakapan Berpikir Kritis, Materi Hukum Newton, Model Problem Based Instruction, Pembelajaran Konvensional

\section{PENDAHULUAN}

Kegiatan pembelajaran dirancang untuk memberikan pengalaman belajar yang melibatkan proses mental dan fisik. Lulusan yang diharapkan setidaknya pebelajar memiliki kompetensi yang meliputi kemampuan pemecahan masalah, berpikir kritis, komunikasi, kesadaran diri, membuat keputusan, berpikir kreatif, hubungan interpersonal, kemampuan vokasional dan sikap positif terhadap kerja.
Pencapaian misi tersebut hendaknya didukung keseimbangan proses pembelajaran antara penguasaan produk sains dan keterampilan proses sains. Penguasaan konsep dalam pembelajaran materi fisika merupakan hal sangat penting. Pentingnya pemahaman konsep dalam proses belajar mengajar sangat mempengaruhi sikap, keputusan, dan cara-cara memecahkan masalah. Guru perlu menekankan pentingnya siswa mempelajari konsep, karena konsep memiliki struktur logis yang membuat fakta dalam konsep 
menjadi bermakna dan berguna untuk diterapkan (Darliana \& Yamin, 2007). Guru dituntut mampu menemukan cara pembelajaran sesuai model pembelajaran yang sesuai dengan pencapaian indikator dalam menyampaikan berbagai konsep materi yang diajarkan sehingga siswa mampu memahami konsep tersebut dan mengimplementasikannya dalam memecahkan masalah dalam kehidupan nyata sehari-hari. Salah satu alternatif yang dapat digunakan adalah pembelajaran berdasarkan masalah atau problem based instruction (PBI). Melalui PBI siswa dituntut untuk menemukan dan mengaplikasikan konsep yang relevan dalam memecahkan masalah autentik. Tanpa penguasaan konsep materi ajar yang memadai, siswa akan menghadapi kendala dalam membuat pijakan landasan berpikirnya.

Disamping memahami konsep materi ajar fisika, siswa juga dituntut cakap dalam memecahkan masalah dalam kehidupan nyata sehari-hari. Kemampuan memecahkan masalah autentik tersebut membutuhkan kecakapan berpikir kritis dalam menganalisis suatu permasalahan. Melalui berpikir kritis akan membekali siswa untuk sebaik mungkin menghadapi informasi yang mereka dengar dan baca, kejadian yang mereka alami, dan keputusan yang mereka buat setiap hari (Ibrahim, 2011). Maknanya bahwa dengan berpikir kritis memungkinkan siswa mampu memecahkan masalah autentik berkaitan dengan aplikasi materi ajar fisika serta menarik kesimpulan yang cerdas dan rasional.

Kelemahan siswa yang sering dijumpai berkenaan dengan kecapakan berpikir kritis adalah ketidakmampuan siswa dalam menganalisis, menggeneralisasi, dan melakukan evaluasi terhadap suatu masalah. Pembelajaran yang dapat meningkatkan kemampuan berpikir kritis adalah melalui belajar berdasarkan masalah dalam kehidupan sehari-hari serta menemukan informasi penting, menganalisis, menarik kesimpulan, mengevaluasi, dan menemukan alternatif penyelesaian dari suatu masalah (Fauziah, 2017). Sependapat dengan hal tersebut, Ngabdiningsih et al., (2013) menyatakan bahwa PBI membantu siswa untuk mengembangkan keterampilan berpikir dan keterampilan mengatasi masalah, mempelajari peran-peran orang dewasa dan menjadi pelajar yang mandiri.

PBI esensinya menyuguhkan berbagai situasi bermasalah yang autentik dan bermakna kepada siswa, yang dapat berfungsi sebagai landasan untuk investigasi atau penyelidikan siswa (Opasana et al., 2016). Melalui investigasi masalah autentik siswa berlatih untuk berpikir merumuskan masalah, menyusun hipotesis, menentukan variabel, mencoba berbagai metode, menganalisis data, menarik kesimpulan, dan mengevaluasi segala sesuatu yang dilakukan.

Materi ajar fisika tentang Hukum Newton memiliki standar kompetensi pemahaman dan penerapan konsep prinsip dasar kinematika dan dinamika dalam kehidupan sehari-hari. Banyak masalah autentik dan fenomena yang dijumpai dalam kehidupan sehari-hari yang dapat dipecahkan dengan menerapkan Hukum Newton. Stigma ini dapat dipahami melalui PBI, karena esensi PBI menyuguhkan masalah autentik dan bermakna kepada siswa yang berfungsi sebagai landasan untuk penyelidikan dan sejalan pula dengan tujuan PBI yaitu mengembangkan kemampuan siswa untuk dapat menyelidiki secara sistematis suatu pertanyaan atau masalah (Bektiarso, 2015). Implementasi PBI pada materi Hukum Newton juga sesuai dengan keinginan BSNP (2006) yang mengacu pada pengembangan fisika yang ditujukan untuk mendidik siswa agar mampu mengembangkan observasi dan eksperimentasi serta berpikir taat asas. Harapan ini didasari oleh tujuan pembelajaran fisika, yakni mengamati, memahami, dan memanfaatkan gejalagejala alam yang melibatkan zat dan energi.

Terkait dengan realita dan uraian tersebut di atas, peneliti bermaksud mengajukan suatu alternatif pemecahan masalah yang ditemukan dalam 
pembelajaran fisika di SMA Negeri Ngoro dengan meneliti implementasi model PBI terhadap penguasaan materi Hukum Newton dan kecakapan berpikir kritis siswa.

\section{METODE PENELITIAN}

Sesuai dengan permasalahan yang akan diteliti, maka jenis penelitian yang akan diterapkan ini tergolong penelitian eksperimen sebenarnya (true experiment). Populasi dalam penelitian ini adalah siswa kelas X SMA Negeri 1 Tuban Kabupaten Tuban tahun pelajaran 2019/2020, yang terdiri dari enam kelas parallel. Penentuan kelas sampel dilakukan dengan menerapkan sampling acak sederhana (simple random sampling) terhadap enam kelas paralel. Berdasarkan penentuan secara random akhirnya terpilih adalah kelas XMIPA1, XMIPA3, XMIPA4, dan XMIPA6. Selanjutnya empat kelas tersebut dirandom untuk menentukan satu kelas kontrol dan tiga kelas eksperimen. Desain penelitian yang digunakan adalah randomized controlgroup pretest-posttest design, dimana kelas eksperimen dan kelas kontrol diberi tes awal (pre tes) dan tes akhir (post tes). Adapun rancangan penelitian seperti tercantum pada Tabel 1 .

Tabel 1

Rancangan Penelitian

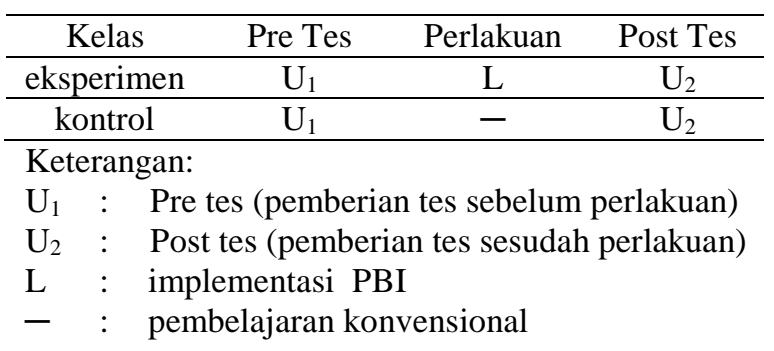

Penelitian ini dilakukan dengan memberikan perlakuan pada kelas kontrol melalui pembelajaran konvensional, sedangkan pada kelas eksperimen dengan mengimplementasikan PBI. Teknik pengambilan data diperoleh dengan cara pemberian observasi, angket, dan melaksnakan tes (pre tes dan post tes). Selanjutnya data dianalisis dengan menggunakan Program Excel dan Program SPSS 12. Data yang dianalisis meliputi aktivitas siswa, penguasaan materi Hukum Newton, dan kecakapan berpikir kritis siswa. Observasi dilakukan oleh dua orang pengamat, yang melakukan pengamatan terhadap aktivitas dan kinerja siswa selama kegiatan belajar mengajar, baik yang mendapat implementasi PBI maupun yang dibelajarkan secara konvensional.

Angket respon siswa berupa penilaian terhadap proses pembelajaran PBI dan perangkat pembelajaran yang digunakan siswa, dengan cara siswa memberi penilaian (baik atau tidak baik) terhadap aspek kegiatan. Tes yang digunakan dalam penelitian ini adalah tes awal (pre tes) dan tes akhir (post tes). Pre tes dilaksanakan pada awal pembelajaran untuk mengetahui kemampuan awal siswa sebelum mempelajari materi pelajaran sesungguhnya. Sedangkan post tes dilaksanakan setelah akhir pembelajaran berfungsi untuk mengetahui seberapa besar keterserapan dan kemampuan siswa menguasai materi Hukum Newton dan kecakapan berpikir kritis siswa setelah diimplementasikan model PBI. Tahapan teknik analisa data yang dilakukan pada penelitian ini meliputi deskripsi kinerja siswa, uji homogenitas, uji normalitas, dan uji hipotesis dengan menerapkan Uji $\mathrm{z}$. Semua analisis data menggunakan program SPSS 17.

\section{HASIL PENELITIAN Deskripsi Aktivitas Siswa}

Skor rata-rata aktivitas siswa yang meliputi aspek psikomotor dan afektif dideskripsikan pada Gambar 1. 


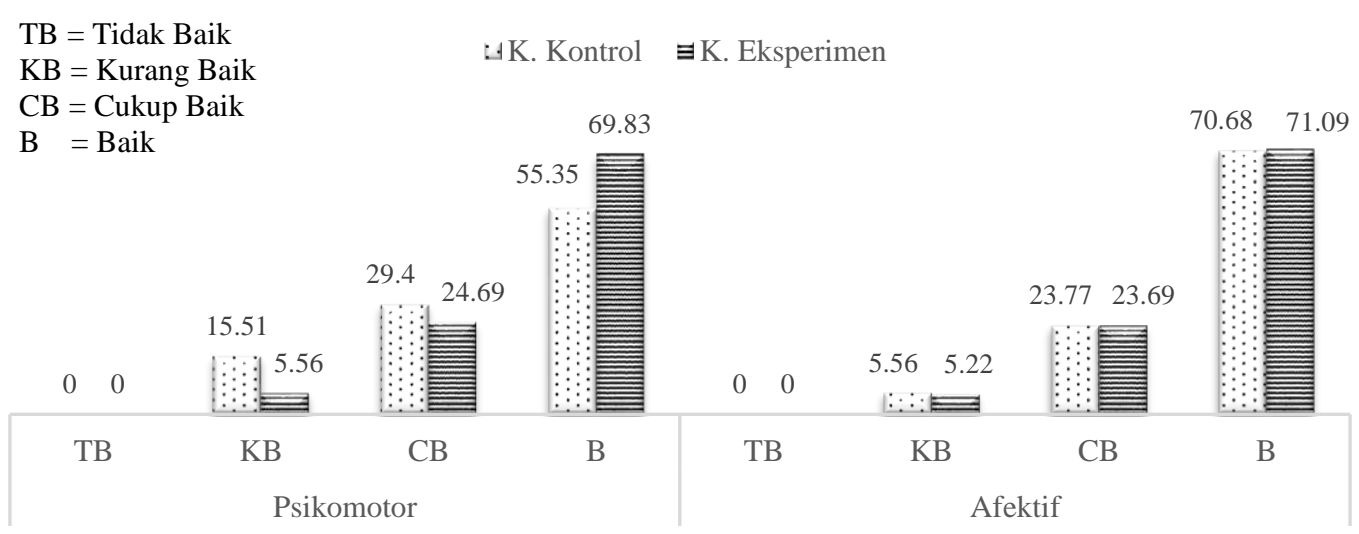

Gambar 1. Aktivitas Psikomotor dan Afektif Siswa

Tampak bahwa pada aspek psikomotor persentase kategori baik untuk kelas eksperimen rata-ratanya lebih tinggi daripada kelas kontrol, sedangkan pada aspek afektif tidak menunjukkan adanya perbedaan yang berarti.

Data Tabel 2 menunjukkan bahwa skor rata-rata pre tes hasil belajar penguasaan materi Hukum Newton pada semua kelompok sampel berada pada kategori sangat kurang karena rentang ratarata nilai yang dicapai $<25,0$. Hasil yang sama juga ditunjukkan pada skor rata-rata untuk kecakapan berpikir kritis siswa.

Tabel 2

Skor Rata-rata Pre Tes

\begin{tabular}{|c|c|c|c|}
\hline $\begin{array}{l}\text { Variabel } \\
\text { Respon }\end{array}$ & Perlakuan & $\begin{array}{c}\text { Rata- } \\
\text { rata }\end{array}$ & $\begin{array}{c}\text { Simpangan } \\
\text { Baku }\end{array}$ \\
\hline \multirow{2}{*}{$\begin{array}{c}\text { Penguasaan } \\
\text { Materi } \\
\text { Hukum } \\
\text { Newton } \\
\text { (PHN) }\end{array}$} & $\begin{array}{c}\text { Pembelajaran } \\
\text { Konvensional } \\
\text { (Kelas } \\
\text { Kontrol) }\end{array}$ & 21,14 & 6,34 \\
\hline & $\begin{array}{c}\text { PBI (Kelas } \\
\text { Eksperimen) }\end{array}$ & 20,11 & 5,12 \\
\hline \multirow[t]{2}{*}{$\begin{array}{c}\text { Kecakapan } \\
\text { Berpikir } \\
\text { Kritis (KBK) }\end{array}$} & $\begin{array}{c}\text { Pembelajaran } \\
\text { Konvensional } \\
\text { (Kelas } \\
\text { Kontrol) }\end{array}$ & 16,56 & 4,40 \\
\hline & $\begin{array}{c}\text { PBI (Kelas } \\
\text { Eksperimen) }\end{array}$ & 15,81 & 3,72 \\
\hline
\end{tabular}

Data Tabel 2 memperlihatkan perbedaan skor rata-rata siswa untuk penguasaan materi Hukum Newton antara yang diajarkan melalui implementasi PBI dan pembelajaran konvensional sangat kecil yaitu sebesar 1,03. Hasil serupa juga ditemukan pada kecakapan berpikir kritis siswa yang perbedaannya hanya sebesar 0,75. Maknanya kemampuan awal siswa kelas kontrol dan kelas eksperimen relatif sama.

Skor rata-rata dan simpangan baku hasil post tes untuk semua kelompok sampel dan semua variabel respon disajikan pada Tabel 3.

Tabel 3

Skor Rata-rata Post Tes

\begin{tabular}{|c|c|c|c|}
\hline $\begin{array}{c}\text { Kelompok } \\
\text { Sampel }\end{array}$ & $\begin{array}{l}\text { Variabel } \\
\text { Respon }\end{array}$ & $\begin{array}{l}\text { Rata- } \\
\text { rata }\end{array}$ & $\begin{array}{c}\text { Simpangan } \\
\text { Baku }\end{array}$ \\
\hline \multirow{2}{*}{$\begin{array}{c}\text { Kelas } \\
\text { Kontrol }\end{array}$} & $\begin{array}{c}\text { Penguasaan } \\
\text { Materi Hukum } \\
\text { Newton }\end{array}$ & 67,28 & 8,48 \\
\hline & $\begin{array}{c}\text { Kecakapan } \\
\text { Berpikir Kritis }\end{array}$ & 62.67 & 9,27 \\
\hline \multirow{2}{*}{$\begin{array}{c}\text { Kelas } \\
\text { Eksperimen }\end{array}$} & $\begin{array}{l}\text { Penguasaan } \\
\text { Materi Hukum } \\
\text { Newton }\end{array}$ & 76,70 & 11,06 \\
\hline & $\begin{array}{c}\text { Kecakapan } \\
\text { Berpikir Kritis }\end{array}$ & 72,89 & 9,71 \\
\hline
\end{tabular}

Data Tabel 3 menunjukkan rata-rata skor penguasaan materi Hukum Newton dan kecakapan berpikir kritis siswa yang diajarkan melalui implementasi PBI lebih tinggi daripada pembelajaran konvensional.

\section{Penguasaan Materi Hukum Newton}

Analisis hipotesis penguasaan materi Hukum Newton didasarkan pada perubahan nilai pre tes dan post tes siswa. Data perubahan nilai rata-rata antara pre tes dan post tes penguasaan materi Hukum Newton disajikan pada data Tabel 4. 
Tabel 4

Perubahan Rata-rata Nilai Pre Tes dan Post Tes PHN

\begin{tabular}{|c|c|c|c|c|}
\hline \multirow[b]{2}{*}{ No. } & \multirow{2}{*}{$\begin{array}{c}\text { Kelas } \\
\text { Penelitian }\end{array}$} & \multicolumn{3}{|c|}{ Nilai Rata-Rata PHN } \\
\hline & & $\begin{array}{l}\text { Pre } \\
\text { Tes }\end{array}$ & $\begin{array}{l}\text { Post } \\
\text { Tes }\end{array}$ & Perubahan \\
\hline 1 & $\begin{array}{c}\text { Kelas } \\
\text { Kontrol }\end{array}$ & 21,14 & 67,28 & 46.14 \\
\hline 2 & $\begin{array}{c}\text { Kelas } \\
\text { Eksperimen } \\
1\end{array}$ & 19,45 & 76,85 & 57,41 \\
\hline 3 & $\begin{array}{c}\text { Kelas } \\
\text { Eksperimen } \\
2\end{array}$ & 28,83 & 78,09 & 59,26 \\
\hline 4 & $\begin{array}{c}\text { Kelas } \\
\text { Eksperimen } \\
3\end{array}$ & 22,07 & 75,15 & 53,09 \\
\hline
\end{tabular}

Data Tabel 4 menunjukkan perubahan rata-rata nilai pre tes dan post tes penguasaan materi Hukum Newton untuk kelas eksperimen lebih tinggi daripada yang diperoleh kelas kontrol. Secara grafik, data Tabel 4 dapat dideskripsikan melalui Gambar 2 berikut.

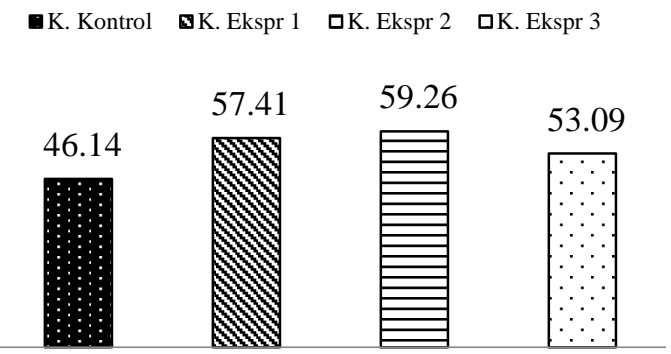

Gambar 2. Perubahan Nilai Rata-rata PHN

Analisis data perubahan nilai rata-rata pre tes dan post tes penguasaan materi Hukum Newton dengan menggunakan analisis uji z disajikan pada Tabel 5 berikut.

Tabel 5

Analisis Data Uji z Perubahan Nilai Pre Tes dan Post Tes PHN

\begin{tabular}{|c|c|c|c|c|c|c|}
\hline \multicolumn{7}{|c|}{ Independent Samples Test } \\
\hline & & \multicolumn{2}{|c|}{$\begin{array}{c}\text { Levene's Test for } \\
\text { Equality of Variances }\end{array}$} & \multicolumn{3}{|c|}{$\begin{array}{c}\text { t-test for Equality of } \\
\text { Means }\end{array}$} \\
\hline & & $100<$ & Sig. & $\mathrm{t}$ & $\mathrm{df}$ & $\begin{array}{c}\text { Sig. } \\
\text { (2-tailed) }\end{array}$ \\
\hline Perubahan Nilai PHN & $\begin{array}{c}\text { Equal variances } \\
\text { assumed }\end{array}$ & .344 & .556 & $\begin{array}{c}4.39 \\
9 \\
\end{array}$ & 142 & .000 \\
\hline $\begin{array}{c}\text { K Eksperimen dan } \\
\text { K Kontrol }\end{array}$ & $\begin{array}{l}\text { Equal variances } \\
\text { not assumed }\end{array}$ & & & $\begin{array}{c}4.68 \\
9\end{array}$ & $\begin{array}{c}67.4 \\
69\end{array}$ & .000 \\
\hline
\end{tabular}

Melalui analisis data dengan menggunakan uji $\mathrm{z}$ pada Tabel 5 yang analisis data secara rinci diperoleh, a) hitung untuk perubahan skor penguasaan materi Hukum Newton (PHN) dengan equal variance assumed adalah 0,344 dengan probabilitas 0,556. Karena probabilitas > 0,05 maka asumsi kedua varians adalah sama; b) z hitung (nilai t) untuk skor penguasaan materi Hukum Newton dengan equal variance assumed adalah 4,399 dengan probabilitas 0,000 . Karena probabilitas < 0,05 maka perubahan ratarata skor penguasaan materi hukum Newton antara kelas kontrol dan kelas ekpserimen adalah berbeda.

Hasil analisis di atas berarti bahwa terdapat perbedaan signifikan penguasaan materi Hukum Newton antara siswa yang diajarkan melalui model PBI dengan pembelajaran konvensional. Kelas eksperimen memiliki rata-rata perubahan nilai penguasaan materi Hukum Newton yang berbeda secara signifikan dengan kelas kontrol, dimana kelas eksperimen rata-rata perubahan nilainya 56,59 lebih tinggi daripada kelas kontrol yang sebesar 46,14. Dapat disimpulkan bahwa implementasi PBI lebih baik dalam meningkatkan penguasaan Hukum Newton daripada pembelajaran konvensional.

\section{Pengujian Hipotesis Kecakapan Berpikir Kritis}

Analisis hipotesis kecakapan berpikir kritis didasarkan pada perubahan nilai pre 
tes dan post tes siswa. Data perubahan nilai pre tes dan post tes kecakapan berpikir kritis siswa disajikan pada data Tabel 6.

Tabel 6

Perubahan Rata-rata Nilai Pre Tes dan Post Tes KBK

\begin{tabular}{cccc}
\hline \multicolumn{4}{c}{ KBK } \\
\cline { 2 - 4 } Kelas Penelitian & $\begin{array}{c}\text { Pre } \\
\text { Tes }\end{array}$ & $\begin{array}{c}\text { Post } \\
\text { Tes }\end{array}$ & Perubahan \\
\hline Kelas Kontrol & 16,56 & 62,67 & 45,62 \\
\hline $\begin{array}{c}\text { Kelas } \\
\text { Eksperimen 1 }\end{array}$ & 15,89 & 73,33 & 55,03 \\
\hline $\begin{array}{c}\text { Kelas } \\
\text { Eksperimen 2 }\end{array}$ & 15,11 & 74,22 & 57,84 \\
\hline $\begin{array}{c}\text { Kelas } \\
\text { Eksperimen 3 }\end{array}$ & 16,44 & 71,11 & 54,67 \\
\hline
\end{tabular}

Berdasarkan data pada Tabel 6 terlihat bahwa perubahan rata-rata nilai pre tes dan post tes kecakapan berpikir kritis siswa untuk kelas eksperimen lebih tinggi daripada yang diperoleh kelas kontrol.
Secara grafik, maka data Tabel 6 dapat dideskripsikan melalui Gambar 3 berikut.

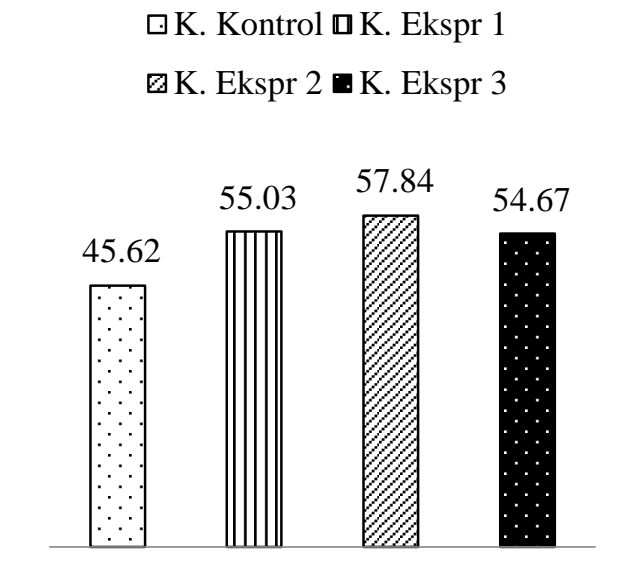

Gambar 3. Perubahan Nilai Rata-rata KBK

Analisis data perubahan nilai ratarata pre tes dan post tes kecakapan berpikir kritis siswa dengan menggunakan analisis uji z disajikan pada Tabel 7 berikut.

Tabel 7

Analisis Data Uji z Perubahan Nilai Pre Tes dan Post Tes KBK

\begin{tabular}{ccccccc}
\hline \multicolumn{7}{c}{ Independent Samples Test } \\
\hline & $\begin{array}{c}\text { Levene's Test for } \\
\text { Equality of Variances }\end{array}$ & t-test for Equality of Means \\
\cline { 2 - 7 } & $\mathrm{F}$ & Sig. & $\mathrm{t}$ & $\mathrm{df}$ & $\begin{array}{c}\text { Sig. } \\
\text { (2-tailed) }\end{array}$ \\
\hline $\begin{array}{c}\text { Perubahan Nilai } \\
\text { PHN }\end{array}$ & $\begin{array}{c}\text { Equal variances } \\
\text { assumed }\end{array}$ & .020 & .990 & 5.399 & 142 & .000 \\
\cline { 2 - 7 } $\begin{array}{c}\text { Equal variances } \\
\text { not assumed } \\
\text { K Eksperimen } \\
\text { dan } \\
\text { K Kontrol }\end{array}$ & & & 5.418 & 60.409 & .000 \\
\hline
\end{tabular}

Melalui analisis data dengan menggunakan uji z pada Tabel 7, a) f hitung untuk perubahan skor kecakapan berpikir kritis (KBK) dengan equal variance assumed adalah 0,020 dengan probabilitas 0,990. Karena probabilitas > 0,05 maka asumsi kedua varians adalah sama; b) z hitung (nilai t) untuk perubahan skor kecakapan berpikir kritis dengan equal variance assumed adalah 5,399 dengan probabilitas 0,000 . Karena probabilitas < 0,05 maka perubahan rata-rata skor kecakapan berpikir kritis antara kelas kontrol dan kelas ekpserimen adalah berbeda.
Hasil analisis di atas berarti bahwa terdapat perbedaan signifikan kecakapan berpikir kritis antara siswa yang diajarkan melalui model PBI dengan pembelajaran konvensional. Kelas eksperimen memiliki rata-rata perubahan nilai kecakapan berpikir kritis yang berbeda secara signifikan dengan kelas kontrol, dimana kelas eksperimen rata-rata perubahan nilainya 55,85 lebih tinggi daripada dengan kelas kontrol yang sebesar 45,62. Dapat disimpulkan bahwa implementasi PBI lebih baik dalam meningkatkan kecakapan berpikir kritis siswa daripada pembelajaran konvensional. Berdasarkan analisis uji $\mathrm{z}$ 
baik terhadap penguasaan materi Hukum Newton dan kecakapan berpikir kritis siswa, dapat disimpulkan bahwa siswa yang diajarkan dengan implementasi PBI lebih baik dalam meningkatkan penguasaan materi Hukum Newton dan kecakapan berpikir kritis daripada melalui pembelajaran konvensional.

\section{PEMBAHASAN}

Aktifitas Psikomotorik dan Afektif Siswa pada Implementasi Model PBI dan Pembelajaran Konvensional

Berdasarkan analisis hasil penelitian aktivitas siswa pada implementasi PBI diperoleh skor rata-rata untuk aktifitas psikomotor lebih tinggi daripada proses pembelajaran dengan menggunakan pembelajaran konvensional. Hal ini sesuai dengan pendapat Widowati, (2009) yang mengatakan bahwa pada implementasi PBI siswa diberikan kesempatan secara luas untuk mengevaluasi gagasannya melalui eksperimen, penyelidikan atau studi lapangan. Pada implementasi PBI menurut Arends (2008) memungkinkan siswa untuk mendapatkan rasa percaya diri atas kemampuannya sendiri, untuk berpikir dan menjadi pebelajar yang self-regulated.

Aspek afektif untuk implementasi model PBI dan pembelajaran konvensional perolehan skor rata-ratanya tidak berbeda secara signifikan. Hal ini menunjukkan bahwa sikap objektif dan jujur dalam menuliskan hasil pengamatan, kerjasama dalam kelompok, dan menghargai pendapat teman untuk kedua model pembelajaran tersebut memiliki pengaruh yang relatif sama. Sikap jujur, objektif, mampu bekerja sama dalam kelompok, dan menghargai pendapat teman merupakan bagian dari keterampilan sosial yang diperlukan dalam pembelajaran sains fisika untuk memupuk sikap ilmiah.

\section{Implementasi Model PBI dan Pembelajaran Konvensional Terhadap Penguasaan Materi Hukum Newton}

Hasil pre tes menunjukkan bahwa hasil belajar penguasaan materi Hukum Newton pada siswa masih sangat kurang.
Data ini menunjukkan bahwa penguasaan konsep awal siswa masih harus dibenahi dan ditingkatkan. Meskipun demikian siswa telah memiliki pengetahuan awal dan konstruksi keilmuan fisika, khususnya tentang materi Hukum Newton. Skor perolehan yang masih rendah ini mengindikasikan perlu dilakukan inovasi pembelajaran fisika di sekolah menengah agar siswa dapat mencapai hasil belajar yang lebih baik dan memiliki kemampuan mengaplikasikan pengetahuan tersebut untuk memecahkan masalah dalam kehidupan nyata sehari-hari.

Berpijak pada hasil perhitungan ratarata skor konversi dan uji hipotesis diperoleh bahwa penguasaan materi Hukum Newton yang dibelajarkan dengan PBI berbeda secara signifikan dibandingkan pembelajaran konvensional. Perolehan skor rata-rata penguasaan materi Hukum Newton dengan mengimplementasikan PBI lebih tinggi daripada siswa dengan pembelajaran konvensional. Hal ini menguatkan hasil penelitian sebelumnya yang telah dilakukan oleh Anggraini et al., (2019).

Implementasi PBI berdasarkan hasil penelitian ini terbukti dapat meningkatkan penguasaan materi Hukum Newton yang ditandai dengan keberhasilan siswa mengerjakan LKS kinerja proses dan melakukan kegiatan praktikum dengan benar. Hal tersebut dapat dilakukan secara baik karena siswa memahami konsep materi ajar Hukum Newton yang telah dibelajarkan. Hasil tersebut sesuai dengan yang dikemukakan Benyahia (2006) bahwa pembelajaran yang menekankan pada siswa belajar secara active learner yang ditandai dengan mengerjakan sesuatu secara fisik. Kenyataan ini membuat proses pemahaman siswa menjadi lebih optimal, karena telah terlibat secara penuh dalam pembelajaran yang menurut Benson et al., (2009) lebih baik sebagai upaya meningkatkan pemahaman siswa daripada hanya mampu mengulang apa yang telah diberikan guru. Apalagi bila ditinjau dari sudut pembelajaran ilmu fisika yang tidak hanya menekankan pada hasil akhir tetapi lebih 
menekankan pada proses pemahaman konsep yang disampaikan guru. Dengan demikian implementasi PBI telah mampu mengembangkan siswa belajar secara active learner dan melibatkan diri secara utuh dalam usaha memahami dan menguasai materi Hukum Newton.

\section{Implementasi Model PBI dan Pembelajaran Konvensional Terhadap Kecakapan Berpikir Kritis}

Perolehan skor rata-rata pre tes menunjukkan bahwa kecakapan berpikir kritis pada siswa masih sangat kurang. Informasi awal ini menunjukkan bahwa penguasaan konsep awal siswa masih harus dibenahi dan ditingkatkan. Meskipun demikian siswa telah memiliki sedikit dasar kemampuan berpikir kritis dalam memecahkan persoalan fisika tentang Hukum Newton. Skor rata-rata perolehan yang masih rendah ini mengindikasikan perlu dilakukan inovasi pembelajaran fisika di sekolah menengah agar siswa dapat mencapai kemampuan berpikir kritis yang lebih baik.

Analisis data hasil perhitungan ratarata skor konversi dan uji hipotesis diperoleh bahwa kecakapan berpikir kritis siswa yang dibelajarkan dengan PBI berbeda secara signifikan dibandingkan pembelajaran konvensional. Perolehan skor rata-rata kecakapan berpikir kritis siswa dengan mengimplementasikan PBI lebih tinggi daripada siswa kelompok dengan pembelajaran konvensional. Hal ini diperkuat hasil penelitian Ibrahim (2011).

Implementasi model PBI berdasarkan hasil penelitian ini terbukti dapat meningkatkan kecakapan berpikir kritis siswa yang ditandai dengan keberhasilan siswa merumuskan masalah autentik, merancang percobaan, dan memecahkan permasalahan yang berkaitan dengan alur berpikir kritis secara benar. Hal ini sesuai dengan yang dikemukakan Arends (2008) bahwa PBI membantu siswa untuk mengembangkan keterampilan berpikir dan keterampilan mengatasi masalah. Dukungan yang kuat juga sejalan dengan pendapat Ibrahim (2011), suatu pembelajaran dapat meningkatkan kemampuan berpikir kritis melalui belajar berdasarkan masalah (PBI) dalam kehidupan sehari-hari, menguraikan masalah, mengajukan asumsi, menggunakan berbagai paradigma, mencoba berbagai metode, memeriksa data, mencari alternatif solusi, dan mengevaluasi segala sesuatu yang dilakukan.

Pentingnya kemampuan berpikir kritis dalam pendidikan modern menurut Schafersman (2006), karena berpikir kritis dimaksudkan sebagai berpikir yang benar dalam pencarian pengetahuan yang relevan dan reliabel tentang dunia nyata. Kemampuan berpikir kritis pada siswa tercermin pada kemampuannya untuk mengajukan pertanyaan yang cocok, mengumpulkan informasi yang relevan, bertindak secara efisien, mengemukakan argumen yang logis berdasarkan informasi, menganalisis, menggeneralisasi, dan melakukan evaluasi terhadap suatu masalah, serta membuat simpulan yang dapat dipercaya.

\section{SIMPULAN}

Terdapat perbedaan aktivitas antara siswa yang diajarkan melalui implementasi model PBI (kelas eksperimen) dan pembelajaran konvensional (kelas kontrol). Pada aspek psikomotor persentase kategori baik untuk kelas eksperimen rata-ratanya lebih tinggi daripada kelas kontrol, sedangkan pada aspek afektif tidak menunjukkan adanya perbedaan yang berarti. Terdapat perbedaan signifikan penguasaan materi hukum Newton antara siswa yang diajarkan melalui implementasi model PBI dengan pembelajaran konvensional. Model PBI lebih baik dalam pencapaian rata-rata perubahan nilai penguasaan materi Hukum Newton yaitu 56,59 daripada pembelajaran konvensional sebesar 46,14. Terdapat perbedaan signifikan kecakapan berpikir kritis antara siswa yang diajarkan melalui implementasi model PBI dengan pembelajaran konvensional. Model PBI lebih baik dalam pencapaian rata-rata perubahan nilai kecakapan berpikir kritis siswa yaitu 55,85 
daripada pembelajaran konvensional sebesar 45,62.

\section{DAFTAR PUSTAKA}

Anggraini, D., Prayekti, N., \& Yusuf, F. I. (2019). Efektivitas Penggunaan Metode Problem Based Intruction (PBI) Terhadap Ketuntasan Hasil Belajar Siswa. Jurnal Pendidikan Matematika \&Matematika. 3(1), 3542.

https://ejournal.unibabwi.ac.id/index. php/transformasi/article/download/39 $7 / 255$

Arends, R. I. (2008). Learning to Teach. Belajar untuk Mengajar. Yogyakarta: Pustaka Pelajar.

Bektiarso, S. (2015). Strategi Pembelajaran. Yogyakarta: LaksBang PRESSindo

Benson, B., Ralp, C. \& Pernol, M. L. (2009). Buku Saku Obstetri \& Ginekologi. Jakarta: EGC

Benyahia, F. (2006). Enabling Students to Cope With Information Overload: The Mind Map Tecnique in Secondary and Higher Education. http://www.engg.uaeu.ac.ae/farid.ben yahia

BNSP. (2006). Kurikulum Tingkat Satuan Pendidikan. Jakarta: Dirjen

Darliana, D., \& Yamin, W. (2007). IPA TERPADU (FIKIBI). Bandung: Depdiknas

Fauziah, F. (2017). Penerapan Pendekatan Creative Problem Solving Terhadap Peningkatan Kemampuan Pemecahan Masalah Matematik Siswa Kelas XII RPL B SMK Negeri 1 Cimahi. Jurnal Ilmiah UPT P2M STKIP Siliwangi, 4(2), 1-6. http://dx.doi.org/10.22460/p2m.v4i2p $1-6.635$

Ibrahim, I. (2011). Pengembangan Kemampuan Berpikir Kritis dan Kreatif Matematis Siswa Melalui Pembelajaran Berbasis-Masalah yang Menghadirkan Kecerdasan Emosional. Seminar Nasional Matematika dan Pendidikan
Matematika Jurusan Pendidikan Matematika FMIPA UNY. Yogyakarta Ngabdiningsih, S. W., Susantini, E., \& Ismono, I. (2013). Penerapan Model Pembelajaran Problem Based Instruction (PBI) Pendekatan Science, Environment, Technology, and Society (SETS) untuk Meningkatkan Hasil Belajar Siswa pada Tema Banjir. Jurnal Pendidikan Sains, 1(2), 714.

https://media.neliti.com/media/public ations/248513-none-71db08e9.pdf

Opasana, I. A. K., Sudana, D. N., \& Rati, N. W. (2016). Pengaruh PBI terhadap Kemampuan Pemecahan Masalah Matematika Siswa Kelas V. e-Journal $P G S D$ Universitas Pendidikan Ganesha, $\quad 4(1), \quad$ 1-10. https://ejournal.undiksha.ac.id/index.p hp/JJPGSD/issue/view/393

Schafersman, S. D. (2006). An Introduction to Critical Thinking. http://freeinquiri: $\quad$ com/criticalthinking.html

Widowati, A. (2009). Pengembangan Critical Thinking melalui Penerapan Model PBL (Problem Based Learning) dalam Pembelajaran Sains. Seminar Nasional Penelitian, Pendidikan dan Penerapan MIPA. UNY. Yogyakarta 